\title{
Peramalan Penjualan Bulanan menggunakan metode Trend Moment pada Toko Suamzu Boutique
}

\author{
Amrullah, Egi Affandi, Wahyu Riansyah, Sobirin \\ Program Studi Sistem Informasi, STMIK Triguna Dharma \\ Jl. A.H Nasution No.73 Medan, Indonesia, 20142
}

\begin{tabular}{|c|c|}
\hline Article Info & ABSTRACT \\
\hline Article history: & beberapa perusahaan untuk mendorong para karyawannya untuk dapat \\
\hline Received Mei $22^{\text {th }}, 2020$ & memenuhi target penjualan. Banyak diperlukan strategi guna untuk memenuhi \\
\hline Revised Jun $24^{\text {th }}, 2020$ & kebutuhan pelanggan yang bervariasi. Suamzu Boutique adalah sebuah Usaha \\
\hline Accepted Jul $18^{\text {th }}, 2020$ & Dagang (U.D) swasta yang bergerak dalam bidang penjualan pakaian selama \\
\hline & $\begin{array}{l}\text { ini mengalami permasalahan berupa penjualan pada bulan yang akan datang } \\
\text { dikarenakan jumlah modal yang terbatas. }\end{array}$ \\
\hline Keyword: & Teknik peramalan dengan metode trend moment digunakan untuk mengetahui \\
\hline Penjualan & jumlah \\
\hline Peramalan & jumlah penjualan yang bulan yang akan datang pada toko Boutique Suamzu. \\
\hline Trend Moment & Dengan \\
\hline & $\begin{array}{l}\text { menggunakan data penjualan selama } 2 \text { tahun terakhir metode trend moment } \\
\text { dapat melakukan predikisi penjualan selama } 12 \text { bulan ke depan. }\end{array}$ \\
\hline & Metode Trend moment memprediksi jumlah Penjualan pada tahun 2020 di \\
\hline & $\begin{array}{l}\text { digunakan untuk peramalan bagi toko untuk menyelesaikan permasalahan } \\
\text { tentang peramalan penjualan pada toko. }\end{array}$ \\
\hline
\end{tabular}

Copyright $\odot 2020$ STMIK Triguna Dharma. All rights reserved.

\author{
Corresponding Author: *First Author \\ Nama : Amrullah \\ Program Studi : Sistem Informasi \\ STMIK Triguna Dharma \\ E- Mail : amrullahmedan1@gmail.com
}

\section{PENDAHULUAN}

Persaingan di bidang bisnis diera globalisasi saat ini yang semakin ketat membuat beberapa perusahaan untuk mendorong para karyawannya untuk dapat memenuhi target penjualan. Banyak diperlukan strategi guna untuk memenuhi kebutuhan pelanggan yang bervariasi, dengan pola dan gaya hidup yang berbeda beda pula. Keberhasilan dari sebuah perusahaan juga harus didukung dengan tingkat penjualan yang dilakukan. Begitu pula karyawan yang dituntut untuk memenuhi target penjualan setiap bulannya harus memutar otak untuk dapat menjual produk secara maksimal.

Permintaan pelanggan yang berubah setiap harinya menuntut para perusahaan lebih detail dalam perencanaan strategi untuk meningkatkan penjualan setiap harinya. Salah satu yang dapat dilakukan pihak manajemen adalah melakukan peramalan penjualan (sales forecasting).

Peramalan adalah data di masa lalu yang digunakan untuk keperluan estimasi data yang akan datang. Peramalan atau Forecasting merupakan bagian terpenting bagi setiap perusahaan ataupun organisasi bisnis dalam setiap pengambilan keputusan manajemen. Peramalan itu sendiri bisa menjadi dasar bagi perencanaan jangka pendek, menengah maupun jangka panjang suatu perusahaan. Ramalan pada dasarnya merupakan dugaan atau perkiraan mengenai terjadinya suatu kejadian atau peristiwa di waktu yang akan datang

Suamzu Boutique adalah sebuah Usaha Dagang (U.D) swasta yang bergerak dalam bidang penjualan pakaian. Suamzu Boutique yang beralamat di Jl. Setia Budi No.108, Tj. Rejo, Kec. Medan Sunggal, Kota Medan, Sumatera Utara 20122 memiliki berbagai macam jenis pakaian dengan hasil desain sendiri dan banyak diminati khususnya di kota Medan dan sekitarnya. Untuk mengetahui penjualan bulanan selama ini hanya dapat diketahui dengan laporan tertulis dari bagian keuangan perusahaan. Dengan mengetahui data penjualan 
yang ada perusahaan tentunya perusahaan ingin mengetahui perkembangan penjualan pada bulan yang akan datang, kesulitan dalam menentukan model dan cara untuk mengetahui penjualan pada bulan yang akan datang tentunya akan dapat diselesaikan dengan model peramalan (Forecast)

Teknik peramalan merupakan cara memperkirakan apa yang akan terjadi pada masa mendatang secara sistematis dan pragmatis atas dasar data yang relevan pada masa yang lalu, sehingga dengan demikian teknik peramalan diharapkan dapat memberikan objectivitas yang lebih besar.

Dengan Menganalisa data transaksi penjualan setiap bulannya yang telah terjadi diharapkan akan memudahkan bagian keuangan untuk mendapatkan informasi peramalan tentang penjualan pada bulan yang akan datang, serta diharapkan akan mengurangi atau bahkan menemukan permasalahan yang ada.

\section{METODE PENELITIAN}

Dalam menyusun skripsi ini metode penelitian dalam pengumpulan data adalah sebagai berikut :

a. Observasi

Pengamatan ini dilakukan dilakukan secara langsung turun kelapangan sehingga mendapatkan datadata yang lebih pasti dan akurat. Penelitian ini juga dilakukan langsung di Boutique Suamzu yang beralamat di Jl. Setia Budi No.108, Tj. Rejo, Kec. Medan Sunggal, Kota Medan, Sumatera Utara 20122.

b. Studi Kepustakan

Jenis penilitian ini dilakukan dengan mengumpulkan data-data yang ada hubungannya dengan skripsi ini yang bersifat teoritis, sebagian diambil dari browsing internet dan bahan kuliah yang dipelajari yang berhubungan dengan penelitian ini.

c. Analisa Kebutuhan

Dalam langakah ini merupakan analisa terhadap kebutuhan sistem. Pengumpulan data dalam tahap ini bisa melakukan sebuah penelitian, wawancara atau study literatur. Seseorang sistem analisis akan menggali informasi sebanyak-banyaknya dari bagian keuangan sehingga akan tercipta model preramalan bisa melakukan tugas-tugas yang diinginkan oleh bagian keuangan.

\subsection{Metode Trend Moment}

Trend Moment atau sering disebut Secular Trend adalah metode peramalan Time-Series yang menyesuaikan garis trend pada sekumpulan data masa lalu dan kemudian diproyeksikan dalam garis untuk meramalkan masa depan untuk peramalan jangka pendek atau jangka panjang. Jika hal yang diteliti menunjukkan gejala kenaikan maka trend yang kita miliki menunjukkan rata-rata pertambahan, sering disebut trend positif, tetapi hal yang kita teliti menunjukkan gejala yang semakin berkurang maka trend yang kita miliki menunjukkan rata-rata penurunan atau disebut juga trend negative [1].

Pada penelitian ini metode forecasting yang digunakan adalah trend moment. Trend Moment merupakan metode untuk mencari garis trend dengan perhitungan statistika dan matematika tertentu guna mengetahui fungsi garis lurus sebagai pengganti garis patah-patah yang dibentuk oleh data historis perusahaan. Kelebihan dari metode trend moment dibandingkan dengan metode lainnya terletak pada penggunaan parameter X yang dipakai, sehingga tidak ada perbedaan apakah data yang dipakai merupakan data historis berjumlah genap ataukah ganjil, karena nilai dalam parameter X selalu di mulai dengan nilai 0 sebagai urutan pertama.[2]

Dalam penerapan metode Trend Moment dapat di lakukan dengan menggunakan data historis dari satu variabel, adapun rumus yang di gunakan adalah [3] :

$$
Y=a+b X
$$

Dimana:

$\mathrm{Y}=$ nilai trend atau variabel yang akan diramalkan

$\mathrm{a}=$ bilangan konstan

$\mathrm{b}=$ slope atau koefisien garis trend

$\mathrm{X}=$ indeks waktu (dimulai dari $0,1,2, \ldots . \mathrm{n}$ )

Untuk mencari nilai a dan $\mathrm{b}$ pada rumus diatas, digunakan dengan cara matematis dengan penyelesaiannya menggunakan metode subtitusi dan metode eliminasi. Adapun persamaannya yaitu (M.T. Khifin, 5)[4][4]:

$$
\begin{gathered}
\sum y=a \cdot n+b \cdot \sum x \\
\sum x y=a . \sum x+b . \sum x^{2}
\end{gathered}
$$


Dimana:

$\sum \mathrm{y}=$ jumlah dari data penjualan

$\sum \mathrm{x}=$ jumlah dari periode waktu

$\sum x y=$ jumlah dari data penjualan dikali dengan periode waktu

$\mathrm{n}=$ jumlah data

Setelah nilai ramalan yang telah diperoleh dari hasil peramalan dengan metode Trend Moment akan dikoreksi terhadap pengaruh musiman dengan menggunakan indeks musim. Adapun algoritma dari metode trend moment yaitu:

1. Menentukan jumlah data penjualan yang akan digunakan sebagai peramalan penjualan stok.

2. Menentukan nilai $X$, nilai $Y$, nilai $X \times Y$ dan nilai $X 2$.

3. Menentukan total jumlah nilai $X$, nilai $Y$, nilai $X \times Y$ dan nilai $X 2$ berdasarkan data penjualan.

4. Menentukan rata-rata nilai $X$, nilai $Y$, nilai $X \times Y$ dan nilai $X 2$ berdasarkan data penjualan.

5. Menentukan nilai $b$ dengan menggunakan rumus.

6. Menentukan nilai a dengan menggunakan rumus.

$$
b=\frac{n\left(\sum X Y\right)-\left(\sum X\right)\left(\sum Y\right)}{n\left(\sum X^{2}\right)-\left(\sum X\right)^{2}}
$$

$$
a=\frac{\left(\sum Y\right)-b\left(\sum X\right)}{n}
$$

7. Menentukan nilai indeks musim dengan menggunakan rumus.

$$
i m=\frac{\text { rata }- \text { rata penjualan bulan yang akan diramalkan }}{\text { rata }- \text { rata penjualan keseluruhan }}
$$

8. Mencari nilai $\mathrm{Y}$ yang akan diramalkan dengan menggunakan rumus.

$$
Y=a+b x
$$

\section{ANALISA DAN HASIL}

\subsection{Analisa Data}

Pengumpulan data berupa data penjualan pada Toko Suamzu Boutique. Pengumpulan data dilakukan dengan menganalisa data penjualan setiap bulannya berdasarkan jumlah item terjual atau transaksi pada setiap barang yang di buat dalam laporan bulanan. Data yang digunakan adalah data penjualan dalam kurun waktu 2 tahun mulai dari bulan Januari 2018 sampai dengan desember 2019. Berikut ini merupakan data yang telah dibuat dalam bentuk-laporan excel berdasarkan penjualan setiap bulannya selama 2 tahun yang akan digunakan untuk melakukan peramalan pada bulan yang akan datang dengan menggunakan metode Trend Moment.

Tabel 3.1 Data Penjualan bulanan Toko Suamzu Boutique

\begin{tabular}{|r|l|c|}
\hline NO & Bulan & Penjualan (Rp.) \\
\hline 1 & Januari 2018 & $47,878,000.00$ \\
\hline 2 & Februari 2018 & $33,112,000.00$ \\
\hline 3 & Maret 2018 & $34,193,000.00$ \\
\hline 4 & April 2018 & $35,491,000.00$ \\
\hline 5 & Mei 2018 & $34,741,000.00$ \\
\hline 6 & Juni 2018 & $34,279,000.00$ \\
\hline 7 & Juli 2018 & $42,096,000.00$ \\
\hline 8 & Agustus 2018 & $36,717,000.00$ \\
\hline 9 & September 2018 & $36,687,000.00$ \\
\hline 10 & Oktober 2018 & $38,982,000.00$ \\
\hline 11 & November 2018 & $38,157,000.00$ \\
\hline 12 & Desember 2018 & $39,695,000.00$ \\
\hline 13 & Januari 2019 & $51,245,000.00$ \\
\hline 14 & Februari 2019 & $35,168,000.00$ \\
\hline 15 & Maret 2019 & $36,426,000.00$ \\
\hline 16 & April 2019 & $38,094,000.00$ \\
\hline 17 & Mei 2019 & $31,032,000.00$ \\
\hline 18 & Juni 2019 & $38,960,000.00$ \\
\hline 19 & Juli 2019 & $37,768,000.00$ \\
\hline 20 & Agustus 2019 & $35,734,000.00$ \\
\hline 21 & September 2019 & $34,746,000.00$ \\
\hline & & \\
\hline
\end{tabular}




\begin{tabular}{|l|l|l|}
22 & Oktober 2019 & $69,172,000.00$ \\
\hline 23 & 'November 2019 & $31,603,000.00$ \\
\hline 24 & Desember 2019 & $32,510,000.00$ \\
\hline
\end{tabular}

Sumber: Toko Suamzu Boutique

\subsection{Analisa Metode Trend Moment}

\section{Menentukan Jumlah Data Penjualan}

Data yang digunakan untuk peramalan adalah sebanyak 24 data berdasarkan jumlah bulan selama 2 tahun mulai dari bulan januari 2018 sampai dengan bulan desember 2019. Data pada tabel 3.1 adalah data penjualan pada bulan Januari 2018 dengan total penjualan sebanyak 47,878,000. Dengan melakukan konversi nilai data yaitu mengurangi 3 digit angka dari belakang untuk memudahkan proses perhitungan Trend Moment.

Table 4.2 Data Penjualan yang digunakan untuk Peramalan

\begin{tabular}{|l|l|c|}
\hline No & Bulan & Penjualan \\
\hline 1 & Januari 2018 & 47,878 \\
\hline 2 & Februari 2018 & 33,112 \\
\hline 3 & Maret 2018 & 34,193 \\
\hline 4 & April 2018 & 35,491 \\
\hline 5 & Mei 2018 & 34,741 \\
\hline 6 & Juni 2018 & 34,279 \\
\hline 7 & Juli 2018 & 42,096 \\
\hline 8 & Agustus 2018 & 36,717 \\
\hline 9 & September 2018 & 36,687 \\
\hline 10 & Oktober 2018 & 38,982 \\
\hline 11 & November 2018 & 38,157 \\
\hline 12 & Desember 2018 & 39,695 \\
\hline 13 & Januari 2019 & 51,245 \\
\hline 14 & Februari 2019 & 35,168 \\
\hline 15 & Maret 2019 & 36,426 \\
\hline 16 & April 2019 & 38,094 \\
\hline 17 & Mei 2019 & 31,032 \\
\hline 18 & Juni 2019 & 38,960 \\
\hline 19 & Juli 2019 & 37,768 \\
\hline 20 & Agustus 2019 & 35,734 \\
\hline 21 & September 2019 & 34,746 \\
\hline 22 & Oktober 2019 & 69,172 \\
\hline 23 & November 2019 & 31,603 \\
\hline 24 & Desember 2019 & 32,510 \\
\hline & & \\
\hline
\end{tabular}

\section{Menentukan nilai $X$, nilai $Y$, nilai $X \times Y$ dan nilai $X^{2}$.}

Langkah selanjutnya adalah menentukan nilai $X$ dimana nilai $X$ adalah waktu yang dibuat dalam bentuk nilai dan dimulai dengan nilai 0 sedangkan nilai $Y$ adalah data penjualan pakaian.

Tabel 4.2 Tabel nilai $\mathrm{X}, \mathrm{Y}, \mathrm{X} \times \mathrm{Y}$ dan nilai $\mathrm{X}^{2}$

\begin{tabular}{|l|l|l|l|l|l|}
\hline No & Bulan & $\mathbf{X}$ & $\mathbf{Y}$ & $\mathbf{X} \times \mathbf{Y}$ & $\mathbf{X}^{\mathbf{2}}$ \\
\hline 1 & Januari 2018 & 0 & 47,878 & 0 & 0 \\
\hline 2 & Februari 2018 & 1 & 33,112 & 33,112 & 1 \\
\hline 3 & Maret 2018 & 2 & 34,193 & 68,386 & 4 \\
\hline 4 & April 2018 & 3 & 35,491 & 106,473 & 9 \\
\hline 5 & Mei 2018 & 4 & 34,741 & 138,964 & 16 \\
\hline 6 & Juni 2018 & 5 & 34,279 & 171,395 & 25 \\
\hline 7 & Juli 2018 & 6 & 42,096 & 252,576 & 36 \\
\hline 8 & Agustus 2018 & 7 & 36,717 & 257,019 & 49 \\
\hline 9 & September 2018 & 8 & 36,687 & 293,496 & 64 \\
\hline 10 & Oktober 2018 & 9 & 38,982 & 350,838 & 81 \\
\hline 11 & November 2018 & 10 & 38,157 & 381,570 & 100 \\
\hline 12 & Desember 2018 & 11 & 39,695 & 436,645 & 121 \\
\hline 13 & Januari 2019 & 12 & 51,245 & 614,940 & 144 \\
\hline
\end{tabular}




\begin{tabular}{|l|l|l|l|l|l|}
\hline No & Bulan & $\mathbf{X}$ & $\mathbf{Y}$ & $\mathbf{X} \times \mathbf{Y}$ & $\mathbf{X}^{\mathbf{2}}$ \\
\hline 14 & Februari 2019 & 13 & 35,168 & 457,184 & 169 \\
\hline 15 & Maret 2019 & 14 & 36,426 & 509,964 & 196 \\
\hline 16 & April 2019 & 15 & 38,094 & 571,410 & 225 \\
\hline 17 & Mei 2019 & 16 & 31,032 & 496,512 & 256 \\
\hline 18 & Juni 2019 & 17 & 38,960 & 662,320 & 289 \\
\hline 19 & Juli 2019 & 18 & 37,768 & 679,824 & 324 \\
\hline 20 & Agustus 2019 & 19 & 35,734 & 678,946 & 361 \\
\hline 21 & September 2019 & 20 & 34,746 & 694,920 & 400 \\
\hline 22 & Oktober 2019 & 21 & 69,172 & $1,452,612$ & 441 \\
\hline 23 & November 2019 & 22 & 31,603 & 695,266 & 484 \\
\hline 24 & Desember 2019 & 23 & 32,510 & 747,730 & 529 \\
\hline
\end{tabular}

\section{Menentukan Total Jumlah Nilai $X$, nilai $Y$, nilai $X \times Y$ dan nilai $X^{2}$}

Langkah selanjutnya setelah didapat jumlah data yang akan digunakan adalah melakukan penjumlahan nilai masing-masing nilai yang digunakan. Berikut ini adalah hasil penjumlahan dari masingmasing nilai.

Total nilai $\mathbf{X}=0+1+2+3+4+5+6+7+8+9+10+11+12+13+14+15+16+17+18+19+20$ $+21+22+23$

$$
=276
$$

Total nilai $Y=47,878+33,112+34,193+35,491+34,741+34,279+42,096+36,717+36,687+38,982$ $+38,157+39,695+51,245+35,168+36,426+38,094+31,032+38,960+37,768+$ $35,734+34,746+69,172+31,603+32,510$

$$
=924,486
$$

Total nilai X x Y $=0+33,112+68,386+106,473+138,964+171,395+252,576+257,019+293,496+$ $350,838+381,570+436,645+614,940+457,184+509,964+571,410+496,512$ $+662,320+679,824+678,946+694,920+1,452,612+695,266+747,730$

$$
=\mathbf{1 0 , 7 5 2 , 1 0 2}
$$

Total nilai $\mathbf{X}^{2}=0+1+4+9+16+25+36+49+64+81+100+121+144+169+196+225+256+$ $289+324+361+400+441+484+529$ $=4,324$

Tabel 4.3 Total Jumlah Nilai $X$, nilai $Y$, nilai $X \times Y$ dan nilai $X^{2}$

\begin{tabular}{|l|l|l|l|l|l|}
\hline No & Bulan & $\mathbf{X}$ & $\mathbf{Y}$ & $\mathbf{X} \times \mathbf{Y}$ & $\mathbf{X}^{\mathbf{2}}$ \\
\hline 1 & Januari 2018 & 0 & 47,878 & 0 & 0 \\
\hline 2 & Februari 2018 & 1 & 33,112 & 33,112 & 1 \\
\hline 3 & Maret 2018 & 2 & 34,193 & 68,386 & 4 \\
\hline 4 & April 2018 & 3 & 35,491 & 106,473 & 9 \\
\hline 5 & Mei 2018 & 4 & 34,741 & 138,964 & 16 \\
\hline 6 & Juni 2018 & 5 & 34,279 & 171,395 & 25 \\
\hline 7 & Juli 2018 & 6 & 42,096 & 252,576 & 36 \\
\hline 8 & Agustus 2018 & 7 & 36,717 & 257,019 & 49 \\
\hline 9 & September 2018 & 8 & 36,687 & 293,496 & 64 \\
\hline 10 & Oktober 2018 & 9 & 38,982 & 350,838 & 81 \\
\hline 11 & November 2018 & 10 & 38,157 & 381,570 & 100 \\
\hline 12 & Desember 2018 & 11 & 39,695 & 436,645 & 121 \\
\hline 13 & Januari 2019 & 12 & 51,245 & 614,940 & 144 \\
\hline 14 & Februari 2019 & 13 & 35,168 & 457,184 & 169 \\
\hline 15 & Maret 2019 & 14 & 36,426 & 509,964 & 196 \\
\hline 16 & April 2019 & 15 & 38,094 & 571,410 & 225 \\
\hline 17 & Mei 2019 & 16 & 31,032 & 496,512 & 256 \\
\hline 18 & Juni 2019 & 17 & 38,960 & 662,320 & 289 \\
\hline 19 & Juli 2019 & 18 & 37,768 & 679,824 & 324 \\
\hline 20 & Agustus 2019 & 19 & 35,734 & 678,946 & 361 \\
\hline 21 & September 2019 & 20 & 34,746 & 694,920 & 400 \\
\hline 22 & Oktober 2019 & 21 & 69,172 & $1,452,612$ & 441 \\
\hline 23 & November 2019 & 22 & 31,603 & 695,266 & 484 \\
\hline 24 & Desember 2019 & 23 & 32,510 & 747,730 & 529 \\
\hline & & & & \\
\hline
\end{tabular}




\begin{tabular}{|c|c|l|l|l|l|}
\hline No & Bulan & $X$ & $Y$ & $X \times Y$ & $X^{2}$ \\
\hline \multicolumn{2}{|c|}{ Total } & $\mathbf{2 7 6}$ & $\mathbf{9 2 4 , 4 8 6}$ & $\mathbf{1 0 , 7 5 2 , 1 0 2}$ & $\mathbf{4 , 3 2 4}$ \\
\hline
\end{tabular}

4. Menentukan rata-rata nilai $X$, nilai $Y$ dan nilai $X \times Y$

Langkah selanjutnya adalah menetukan nilai rata-rata dari nilai $\mathrm{X}$, nilai $\mathrm{Y}$ dan nilai $\mathrm{X} \times \mathrm{Y}$.

Rata - rata nilai $\mathbf{X}=0 ; 1 ; 2 ; 3 ; 4 ; 5 ; 6 ; 7 ; 8 ; 9 ; 10 ; 11 ; 12 ; 13 ; 14 ; 15 ; 16 ; 17 ; 18 ; 19 ; 20 ; 21 ; 22$ $; 23$

$$
=\mathbf{1 1 , 5 0}
$$

Rata - rata nilai $\mathbf{Y}=47,878 ; 33,112 ; 34,193 ; 35,491 ; 34,741 ; 34,279 ; 42,096 ; 36,717 ; 36,687 ; 38,982$; 38,$157 ; 39,695 ; 51,245 ; 35,168 ; 36,426 ; 38,094 ; 31,032 ; 38,960 ; 37,768$; 35,$734 ; 34,746 ; 69,172 ; 31,603 ; 32,510$

$$
\mathbf{= 3 8 , 5 2 0}
$$

Rata - rata nilai $\mathbf{X} \times \mathbf{Y}=0 ; 33,112 ; 68,386 ; 106,473 ; 138,964 ; 171,395 ; 252,576 ; 257,019 ; 293,496$; 350,$838 ; 381,570 ; 436,645 ; 614,940 ; 457,184 ; 509,964 ; 571,410 ;$ 496,$512 ; 662,320 ; 679,824 ; 678,946 ; 694,920 ; 1,452,612 ; 695,266$; 747,730

\section{$=448,004$}

Rata - rata nilai $\mathbf{X}^{2}=0 ; 1 ; 4 ; 9 ; 16 ; 25 ; 36 ; 49 ; 64 ; 81 ; 100 ; 121 ; 144 ; 169 ; 196 ; 225 ; 256 ; 289$; $324 ; 361 ; 400 ; 441 ; 484 ; 529$

$=\mathbf{1 8 0 , 1 6 7}$

Tabel 4.7 Rata-rata nilai $\mathrm{X}$, nilai $\mathrm{Y}$ dan nilai $\mathrm{X} \times \mathrm{Y}$

\begin{tabular}{|l|l|l|l|l|l|}
\hline No & Bulan & $\mathbf{X}$ & $\mathbf{Y}$ & $\mathbf{X} \times \mathbf{Y}$ & $\mathbf{X}^{\mathbf{2}}$ \\
\hline 1 & Januari 2018 & 0 & 47,878 & 0 & 0 \\
\hline 2 & Februari 2018 & 1 & 33,112 & 33,112 & 1 \\
\hline 3 & Maret 2018 & 2 & 34,193 & 68,386 & 4 \\
\hline 4 & April 2018 & 3 & 35,491 & 106,473 & 9 \\
\hline 5 & Mei 2018 & 4 & 34,741 & 138,964 & 16 \\
\hline 6 & Juni 2018 & 5 & 34,279 & 171,395 & 25 \\
\hline 7 & Juli 2018 & 6 & 42,096 & 252,576 & 36 \\
\hline 8 & Agustus 2018 & 7 & 36,717 & 257,019 & 49 \\
\hline 9 & September 2018 & 8 & 36,687 & 293,496 & 64 \\
\hline 10 & Oktober 2018 & 9 & 38,982 & 350,838 & 81 \\
\hline 11 & November 2018 & 10 & 38,157 & 381,570 & 100 \\
\hline 12 & Desember 2018 & 11 & 39,695 & 436,645 & 121 \\
\hline 13 & Januari 2019 & 12 & 51,245 & 614,940 & 144 \\
\hline 14 & Februari 2019 & 13 & 35,168 & 457,184 & 169 \\
\hline 15 & Maret 2019 & 14 & 36,426 & 509,964 & 196 \\
\hline 16 & April 2019 & 15 & 38,094 & 571,410 & 225 \\
\hline 17 & Mei 2019 & 16 & 31,032 & 496,512 & 256 \\
\hline 18 & Juni 2019 & 17 & 38,960 & 662,320 & 289 \\
\hline 19 & Juli 2019 & 18 & 37,768 & 679,824 & 324 \\
\hline 20 & Agustus 2019 & 19 & 35,734 & 678,946 & 361 \\
\hline 21 & September 2019 & 20 & 34,746 & 694,920 & 400 \\
\hline 22 & Oktober 2019 & 21 & 69,172 & $1,452,612$ & 441 \\
\hline 23 & November 2019 & 22 & 31,603 & 695,266 & 484 \\
\hline 24 & Desember 2019 & 23 & 32,510 & 747,730 & 529 \\
\hline Total & $\mathbf{2 7 6}$ & $\mathbf{9 2 4 , 4 8 6}$ & $\mathbf{1 0 , 7 5 2 , 1 0 2}$ & $\mathbf{4 , 3 2 4}$ \\
\hline Rata-rata & $\mathbf{1 1 , 5 0}$ & $\mathbf{3 8 , 5 2 0}$ & $\mathbf{4 4 8 , 0 0 4}$ & $\mathbf{1 8 0 , 1 6 7}$ \\
\hline
\end{tabular}

\section{Menentukan nilai b}

Langkah selanjutnya setelah mendapatkan nilai rata-rata adalah menentukan nilai $\mathrm{b}$ dengan menggunakan rumus.

Dimana:

$$
b=\frac{n\left(\sum X Y\right)-\left(\sum X\right)\left(\sum Y\right)}{n\left(\sum X^{2}\right)-\left(\sum X\right)^{2}}
$$

$$
\begin{array}{ll}
\mathrm{n} & =24 \\
\mathrm{X} & =276
\end{array}
$$

Peramalan Penjualan Bulanan menggunakan metode Trend Moment pada Toko Suamzu Boutique (Amrullah, 


$$
\begin{aligned}
& \mathrm{Y} \quad=924,486 \\
& \mathrm{X} \times \mathrm{Y}=10,752,102 \\
& X^{2} \quad=4,324 \\
& b=\frac{n\left(\sum X Y\right)-\left(\sum X\right)\left(\sum Y\right)}{n\left(\sum X^{2}\right)-\left(\sum X\right)^{2}} \\
& b=\frac{24(10,752,102)-(276)(924,486)}{24(4,324)-(276)^{2}} \\
& b=\frac{258,050-255,158136}{103,776-76,176} \\
& b=\frac{2,892,312}{27,600} \\
& b=104.793913043478 \\
& b=104.794
\end{aligned}
$$

\section{Menentukan nilai a}

Setelah nilai b didapat selanjutnya dilakukan penarian nilai a dengan menggunakan rumus.

$$
\begin{aligned}
& a=\frac{\left(\sum Y\right)-b\left(\sum X\right)}{n} \\
& a=\frac{(924,486)-(104.794)(276)}{24} \\
& a=\frac{(924,486)-(28,923)}{24} \\
& a=\frac{895,562.88}{24} \\
& a=\mathbf{3 7 , 3 1 5 . 1 2}
\end{aligned}
$$

\section{Menentukan nilai indeks musim (im)}

Setelah diperoleh nilai a dan b maka untuk meramalkan jumlah penjualan yang akan hitung index musim nilai x yang ke 25 untuk bulan januari adalah 49,561.50. Langkah selanjutnya adalah mencari nilai indeks musim dengan rumus:

$$
\begin{aligned}
& \mathrm{im}=\frac{\text { rata }- \text { rata penjualan bulan yang akan diramalkan }}{\text { rata }- \text { rata penjualan keseluruhan }} \\
& i m=\frac{49,5615}{38,520} \\
& i m=1,2866433021806853582554517133956 \\
& \mathrm{im}=\mathbf{1} . \mathbf{2 9}
\end{aligned}
$$

\section{Mencari nilai Y yang akan diramalkan} ini.

Langkah terakhir dari metode Trend Moment adalah mencari nilai Y yang akan diramalkan berikut

$Y=a+b x$

$Y=37,315.12+(104.794)(25)$

$Y=37,315.12+2,619.85$

$Y=39,934.97$

Dari hasil diatas diketahui bahwa peramalan penjualan pada bulan januari 2020 sebanyak $\mathbf{3 9}$,934.97.

Hasil perhitungan akan dikonversi menjadi rupiah dengan menambahkan 3 digiti angka 0 pada hasil perhitungan menjadi Rp. 39,935,000.097 sebagai perkiraan pada bulan Januari di tahun 2020. Metode trend moment diterapkan untuk menghasilkan prediksi setiap bulan sesuai dengan kebutuhan perusahaan

\section{KESIMPULAN}

Berdasarkan hasil penelitian dan pembahasan Peramalan Penjualan Bulanan menggunakan metode Trend Moment pada Toko Suamzu Boutique diambil beberapa kesimpulan yaitu

1. Permasalahan yang terjadi berkenaan prediksi penjualan pada bulan yang akan datang diselesaikan dengan menerapkan Metode Trend Moment.

2. Metode Trend Moment digunakan untuk membantu pemilik toko dalam memprediksi penjualan pada Toko Suamzu Boutique pada periode 1 bulan mendatang. Berdasarkan riwayat penjualan selama 2 tahun sebelumnya 


\section{REFERENSI}

[1] I. H. Santi and A. R. Saputra, "Prediksi Jumlah Permintaan Telur Ayam Menggunakan Metode Trend Moment," Inform. Mulawarman J. Ilm. Ilmu Komput., vol. 14, no. 2, p. 111, 2019, doi: 10.30872/jim.v14i2.1986.

[2] A. Ahmad and M. Sholihin, "Trend Moment Method for predicting Multimedia Equipment Rental Needs," vol. 5, no. 1, pp. 20-24, 2020.

[3] I. R. Yanto, I. N. Farida, and M. Bilal, "PENERAPAN METODE TREND MOMENT DALAM FORECASTING PENJUALAN KASUR BUSA DI MEBEL ANUGERAH CUKIR JOMBANG,” J. Chem. Inf. Model., vol. 53, no. 9, pp. 1689-1699, 2018, doi: 10.1017/CBO9781107415324.004.

[4] A. D. I. Kurniawan, U. Nusantara, P. Guru, and R. Indonesia, "Unp kediri 2015," Sist. Rekom. Smartphone Android Menggunakan Metod. Hybrid (Content-Based Dan Collab., 2015

[5] Rosa, A.S., \& Shalahuddin, M. (2015). Rekayasa Perangkat Lunak: Terstruktur dan Berorientasi Objek. Bandung: Informatika.. 